\title{
Spray drift and droplet spectrum from dicamba sprayed alone or mixed with adjuvants using air-induction nozzles
}

\author{
Guilherme Sousa Alves ${ }^{(1)}$, Greg Robert Kruger(2) and João Paulo Arantes Rodrigues da Cunha(1)
}

\begin{abstract}
(1)Universidade Federal de Uberlândia, Instituto de Ciências Agrárias, Caixa Postal 593, CEP 38408-100 Uberlândia, MG, Brazil. E-mail: guilhermeagro43@yahoo.com.br, jpcunha@ufu.br (2)University of Nebraska-Lincoln, West Central Research and Extension Center, Zip Code 69101 North Platte, NE, USA. E-mail: greg.kruger@unl.edu
\end{abstract}

\begin{abstract}
The objective of this work was to evaluate the spray drift and droplet spectrum of dicamba applied alone or with potential drift-reducing adjuvants, using air-induction flat fan nozzles. Standard (XR and TT) and air-induction (AIXR and TTI) nozzles were evaluated in a wind tunnel. The adjuvants used were polymer, ammonium sulfate, vegetable oil, and phosphatidylcholine. The applications were conducted at 276 $\mathrm{kPa}$ pressure and $3.5 \mathrm{~m} \mathrm{~s}^{-1}$ wind speed. The droplet spectrum was measured using a laser diffraction system. Round strings were used as drift collectors, positioned perpendicularly to the wind direction, at 2, 3, 4, 5, 6, 7 , and $12 \mathrm{~m}$ from the nozzle. Drift was calculated by quantifying, through fluorimetry, a fluorescent tracer added to each solution at $1 \mathrm{~g} \mathrm{~L}^{-1}$. Droplet spectrum and dicamba drift depend on the interaction between spray composition and nozzle type. Air-induction nozzles are more recommended for dicamba applications, especially the TTI nozzle. Polymer and ammonium sulfate increase droplet size in all nozzle types, which may reduce drift to nearby crops.
\end{abstract}

Index terms: air-induction nozzle, droplet size, herbicide drift, nozzle type, wind tunnel.

\section{Deriva e espectro de gotas de dicamba pulverizado, com ou sem adjuvantes, com uso de pontas com indução de ar}

\begin{abstract}
Resumo - O objetivo deste trabalho foi avaliar a deriva e o espectro de gotas provenientes de aplicações de dicamba, com ou sem adjuvantes com potencial de redução de deriva, com uso de pontas de jato plano com indução de ar. Foram avaliadas pontas-padrão (XR e TT) e pontas com indução de ar (AIXR e TTI) em túnel de vento. Os adjuvantes usados foram polímero, sulfato de amônio, óleo vegetal e fosfatidilcoline. As aplicações foram feitas à pressão de $276 \mathrm{kPa}$ e à velocidade do vento de $3,5 \mathrm{~m} \mathrm{~s}^{-1}$. O espectro de gotas foi avaliado por um sistema de difração a laser. Fios de nylon foram usados como coletores de deriva, posicionados transversalmente à direção do vento, a 2, 3, 4, 5, 6, 7 e $12 \mathrm{~m}$ da ponta de pulverização. A deriva foi calculada pela quantificação, por fluorimetria, de um corante fluorescente adicionado à calda à concentração de $1 \mathrm{~g}$ $\mathrm{L}^{-1}$. O espectro de gotas e a deriva de dicamba dependem da interação entre a composição da calda e o tipo de ponta de pulverização utilizada. Pontas de pulverização com indução de ar são mais recomendadas nas aplicações de dicamba, especialmente a ponta TTI. O polímero e o sulfato de amônio aumentam o tamanho das gotas em todos os tipos de pontas, o que pode reduzir a deriva para culturas adjacentes.
\end{abstract}

Termos para indexação: ponta com indução de ar, tamanho de gota, deriva de herbicida, tipo de ponta de pulverização, túnel de vento.

\section{Introduction}

Dicamba is an auxin-type herbicide that has been used for more than 40 years to control most of the broadleaf weeds (Behrens et al., 2007). In the last two decades, its use has increased due to the expanding problem of glyphosate-resistant weeds. Currently, 21 broadleaf weed species are known to be resistant to glyphosate, 18 of which have biotypes that are resistant to glyphosate and other herbicide types in the world (Heap, 2017).
Recent introductions of genetically modified varieties of soybean and cotton which tolerate growthregulator herbicides, including dicamba, allow this compound to be used with a greater flexibility. However, susceptible crops may be exposed to nontarget herbicide drift. From the past experience, it is well known that soybean and cotton are both naturally and highly sensitive to low-dose exposures of dicamba. Egan et al. (2014) showed, in a meta-analysis study, that soybean is more susceptible to the herbicide

Pesq. agropec. bras., Brasília, v.53, n.6, p.693-702, June 2018 DOI: $10.1590 / \mathrm{S} 0100-204 X 2018000600005$ 
than cotton during the flowering stage. Andersen et al. (2004) applied 11 and $56 \mathrm{~g} \mathrm{ha}^{-1}$ a.e. on soybean, at V3 stage, and observed, respectively, 14 and $71 \%$ yield reduction.

Several studies have shown that the dicamba spray drift is phytotoxic to a great number of broadleaf crops, including potato, sunflower, and soybean (Haderlie et al., 1986; Derksen, 1989; Weidenhamer et al., 1989). Moreover, Behrens et al. (2007) have shown that damage symptoms caused by dicamba are pronounced on nontransgenic tobacco plants, even at low doses (17 $\mathrm{g} \mathrm{ha}^{-1}$ a.e.), and quite severe at $560 \mathrm{~g} \mathrm{ha}^{-1}$ a.e., a common dose used for weed control in agricultural applications.

Many drift reduction technologies (DRTs) are available for use, such as spray nozzle types, sprayer modifications, spray delivery assistance, spray property modifiers (adjuvants), and landscape modifications (Hoffmann et al., 2010). Spanoghe et al. (2007) have mentioned that the nozzle performance is likely to be strongly affected by liquid properties, and, therefore, by the addition of adjuvants. Similarly, the way in which an individual adjuvant acts depends on the nozzle type used, which makes it difficult to generalize the effect of adjuvants on the formation of sprays. Therefore, it is important to evaluate each application condition, considering that the results do not follow a standard. In this sense, few studies have been done on dicamba drift using DRTs, such as airinduction nozzles and drift retardant adjuvants.

The objective of this work was to evaluate the effects of dicamba, associated or not with four potential drift retardant adjuvants, sprayed using standard and airinduction flat fan nozzles, on droplet spectrum and on drift in a wind tunnel.

\section{Materials and Methods}

The experiment was carried out in the pesticide application technology laboratory, in 2015, at the West Central Research and Extension Center of the University of Nebraska-Lincoln, in North Platte, NE, USA. A completely randomized design was used, with a $5 \times 4 \times 7$ split-split-plot arrangement and four replicates. Main-plot, sub-plot, and sub-sub-plot consisted of five spray compositions, four nozzle types, and seven downwind distances from the nozzle, respectively. The evaluated spray compositions were: dicamba; dicamba + polymer; dicamba + ammonium sulfate; dicamba + vegetable oil; and dicamba + phosphatidylcholine. The commercial product Clarity (Basf, Research Triangle Park, NC, USA) was used as a source of dicamba, at $1.2 \mathrm{~L} \mathrm{ha}^{-1}\left(561 \mathrm{~g} \mathrm{ha}^{-1}\right.$ a.e.) rate. The adjuvants used and their respective rates are described in Table 1. All rates were based on the manufacturer's recommendation. In addition, a PTSA fluorescent tracer (1,3,6,8-pyrenetetrasulfonic acid tetrasodium salt) (Spectra Colors Corp., Kearny, NJ, USA) was added to the solutions at $1 \mathrm{~g} \mathrm{~L}^{-1}$, in order to allow of the detection by fluorimetry afterwards (Hoffmann et al., 2014).

Solutions were sprayed using a single and static ISO 110015 flat fan nozzle (Spraying Systems Co., Wheaton, IL, USA): standard, XR-Extended Range and TT-Turbo Teejet; and an air-induction nozzle, using AIXR-Air Induction Extended Range and TTITurbo Teejet Induction. The spraying pressure used was $276 \mathrm{kPa}$ and solutions were applied at $200 \mathrm{~L} \mathrm{ha}^{-1}$ carrier volume. Environmental conditions during the applications were kept at $20^{\circ} \mathrm{C}\left( \pm 2^{\circ} \mathrm{C}\right)$, and 60 to $70 \%$ relative air humidity.

Drift was determined in accordance to the ISO 22856 Standard (ISO, 2008), with few modifications. The present study was conducted twice, separated temporally to represent two experimental runs. All conditions were the same in both runs.

The wind tunnel had acrylic glass walls and a square working section of $1.2 \mathrm{~m}$ wide, $1.2 \mathrm{~m}$ high, and $15 \mathrm{~m}$ long. An axial fan (Hartzell Inc., Piqua, $\mathrm{OH}$, USA) was used to generate and move the air flow into an expansion chamber located in front of the tunnel. Applications were performed at $3.5 \mathrm{~m} \mathrm{~s}^{-1}$ wind speed, and each replicate consisted of a continuous 10 -seconds application, controlled by a digital auto shut off timer switch (Intermatic Inc., EI 400C, Spring Grove, IL, USA).

All distances were sprayed at the same time and each set was considered as one replicate. Prior to each application, drift collectors, composed of 2 $\mathrm{mm}$ diameter colourless round strings (Blount Inc., Magnum Gatorline, Portland, OR, USA), with $1.0 \mathrm{~m}$ length, were positioned at 2, 3, 4, 5, 6, 7, and $12 \mathrm{~m}$ downwind from nozzle, parallel to the tunnel floor, and perpendicular to the wind direction (Figure 1). Collectors were placed $0.1 \mathrm{~m}$ above the tunnel floor, and the nozzle, $0.6 \mathrm{~m}$ above it, in the longitudinal center of the wind tunnel; a $1.2 \times 0.5 \mathrm{~m}$ rug with polyethylene blades $1.0 \mathrm{~cm}$ tall (GrassWorx LLC., St. Louis, MO, 
USA) was positioned on the sprayed area for absorbing the droplets.

Once the application was performed, the strings were collected and placed individually into pre-labeled plastic bags with $0.95 \mathrm{~L}$ capacity, and then placed into a dark container in order to prevent photodegradation of the tracer. In laboratory, $50 \mathrm{~mL}$ of 1:9 isopropyl alcohol:destilled water solution was added to each plastic bag, using a bottle top dispenser 60000-BTR (LabSciences Inc., Reno, NV, USA). Samples were then swirled and shaken to release the fluorescent material. After the tracer was suspended in solution, a $1.5 \mathrm{~mL}$ aliquot from each sample bag was drawn to fill a glass cuvette, which was placed in a fluorometer Trilogy 7200.000 (Turner Designs, Sunnyvale, CA, USA), using ultraviolet light to collect fluorescence data. The percentage of drift for each distance was calculated in accordance to the ISO Standard, using equations $\beta_{\text {dep }}=f_{\text {flow }} \times f_{\text {conc }} \times V_{\text {dil }} \times\left(\rho_{\text {sample }}-\rho_{\text {blank }}\right) / \rho_{\text {spray }}$, and Drift $(\%)=\left(\beta_{\text {dep }} \times \mathrm{C}_{\text {lenght }}\right) /\left(\mathrm{C}_{\text {diameter }} \times \mathrm{A}_{\text {time }} \times \mathrm{R}_{\text {flow }}\right) \times 6$, in whic: $\beta_{\text {dep }}$ is the spray drift deposit $(\mathrm{mL}) ; \rho_{\text {sample }}$ is the fluorometer reading of the sample $\left(\mathrm{mg} \mathrm{L}^{-1}\right)$; $\rho_{\text {blank }}$ is the fluorometer reading of the blanks (collector + extractor solution; $\left.\mathrm{mg} \mathrm{L}^{-1}\right) ; \rho_{\text {spray }}$ is the referential solution concentration $\left(\mathrm{g} \mathrm{L}^{-1}\right) ; \mathrm{f}_{\text {flow }}$ is the adjustment factor for flow rate; $f_{c o n c}$ is the adjustment factor for tracer concentration from spray; $\mathrm{V}_{\mathrm{dil}}$ is the dilution liquid volume $(\mathrm{L})$ used to solute tracer from collector; $\mathrm{C}_{\text {lenght }}$ is the drift collector length ( $\left.\mathrm{mm}\right) ; \mathrm{C}_{\text {diameter }}$ is the drift collector diameter ( $\mathrm{mm}$ ); $\mathrm{A}_{\text {time }}$ is the application time (s); and $\mathrm{R}_{\text {flow }}$ is the flow rate of a referential nozzle $\left(\mathrm{L} \mathrm{min}^{-1}\right)$.

The droplet spectrum produced by each nozzle type was measured using a Sympatec Helos-Vario $\mathrm{K} / \mathrm{R}$ laser diffraction droplet sizing system (Sympatec Inc., Clausthal, Germany), setup with a R7 lens, with a dynamic size range of 9 to $3,700 \mu \mathrm{m}$. This system was integrated into the wind tunnel, and the wind speed was maintained at $6.7 \mathrm{~m} \mathrm{~s}^{-1}$ during data acquisition (Fritz et al., 2014). The pressure was the same used for drift determination $(276 \mathrm{kPa})$, and the distance from the nozzle tip to the laser was $0.3 \mathrm{~m}$. Three replicated measurements were made for each treatment; and each replicate consisted of a complete vertical traverse of the spray plume. Spray parameters of interest were the diameter $(\mu \mathrm{m})$ of 10,50 , and $90 \%$ of the droplets $\left(D_{\mathrm{v} 0.1}\right.$, $\mathrm{D}_{\mathrm{v} 0.5}$, and $\mathrm{D}_{\mathrm{v} 0.9}$, respectively); and volume percentage of droplets smaller than $100 \mu \mathrm{m}\left(\mathrm{V}_{100}\right)$.

Normality of residuals and homogeneity of variance of drift data were analyzed by the KolmogorovSmirnov's and Levene's tests, respectively, using SPSS Statistical Software, version 17.0 (SPSS Inc.,

Table 1. Adjuvant rates recommended by the manufacturer.

\begin{tabular}{lccc}
\hline Adjuvant & Commercial name & Rate (v v $\left.{ }^{-1}\right)$ & Manufacturer \\
\hline Polymer & Affect GC & 0.03 & United Suppliers Inc., Eldora, IA, USA \\
Ammonium sulfate & Border Xtra 8L & 2.50 & Precision Laboratories LLC., Waukegan, IL, USA \\
Vegetable oil & In-Place & 0.69 & Wilbur-Ellis, Fresno, CL, USA \\
Phosphatidylcholine & LI 700 & 0.50 & Loveland Products Inc., Greeley, CO, USA \\
\hline
\end{tabular}

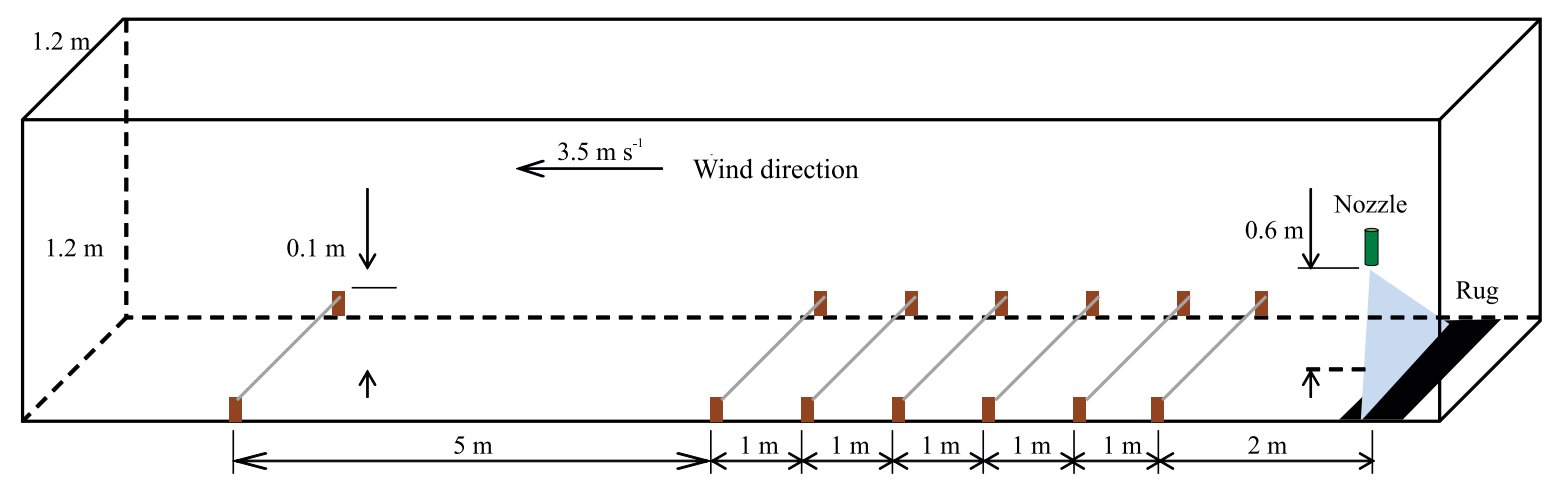

Figure 1. Schematic drawing detailing the positions of nozzle and drift collectors in the wind tunnel. 
Chicago, IL, USA). In cases that the assumptions were significant at $1 \%$ probability, drift and $\mathrm{V}_{100}$ data were transformed by arc sine $\left[(\mathrm{x} / 100)^{0.5}\right]$, whilst $\mathrm{D}_{\mathrm{v} 0.1}$, $\mathrm{D}_{\mathrm{v} 0.5}$, and $\mathrm{D}_{\mathrm{v} 0.9}$ data were transformed by $(\mathrm{x}+0.5)^{0.5}$. Assumptions from the original drift and $\mathrm{V}_{100}$ data did not reach the $1 \%$ significance threshold, therefore, data were transformed before the comparisons between treatments, in both runs. For the other variables, the analysis of variance was conducted, and drift and $\mathrm{V}_{100}$ data (original and transformed) were subjected to it using the Sisvar Statistical Software, version 5.6 (Ferreira, 2011). Nozzles and solutions were compared to each other, within each evaluated distance, by the Tukey's multiple comparison test, whereas regression analysis was performed for the distances, at 5\% probability.
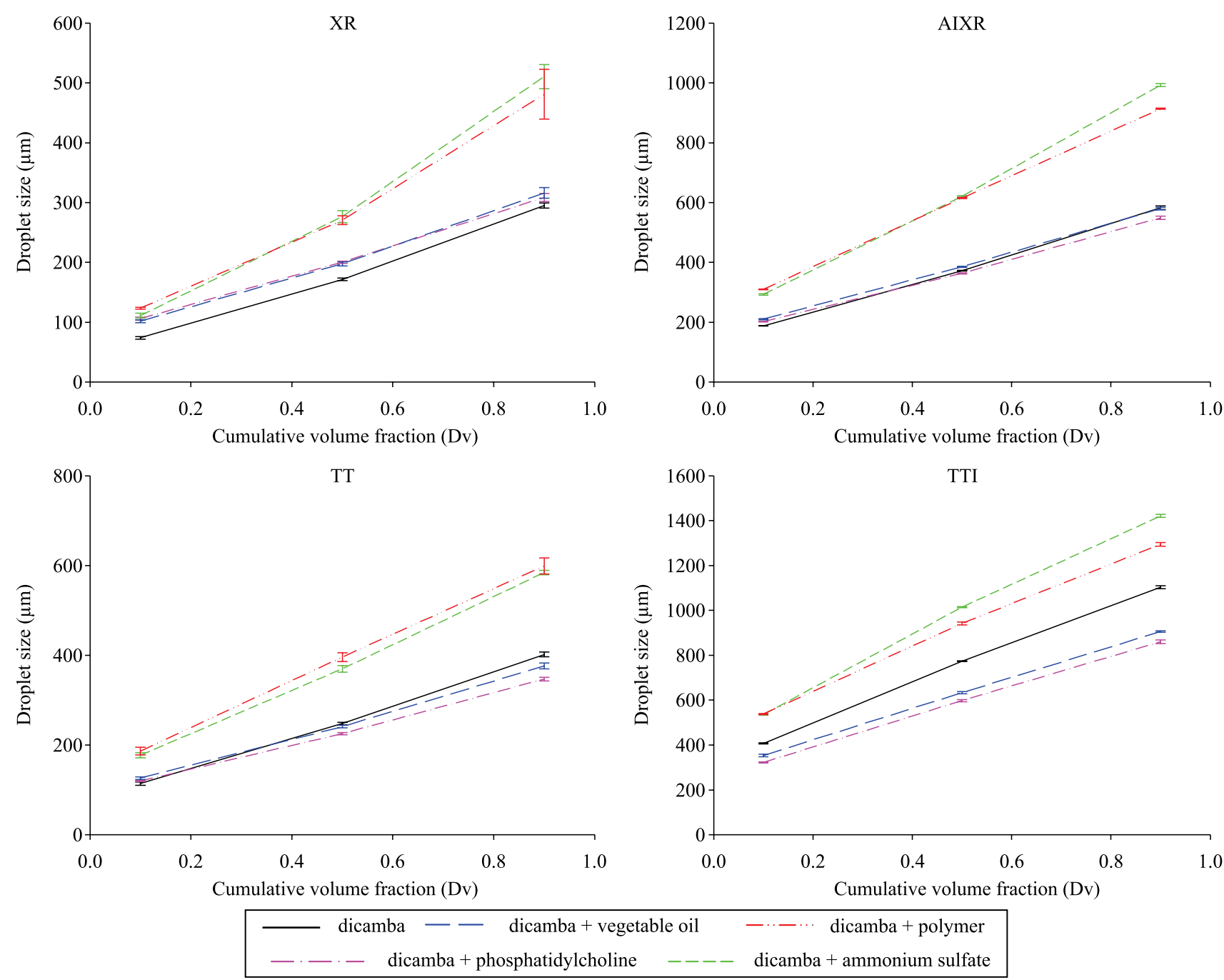

Figure 2. Droplet diameter below with the cumulative volume fraction $\left(D_{v 0.1}, D_{v 0.5}, D_{v 0.9}\right)$ produced through different nozzle types in applications of dicamba alone and with adjuvants.

Two-parameter exponential functions $\left(\hat{\mathrm{y}}=\mathrm{ae}^{\mathrm{bx}}\right)$ were adjusted based on significance and coefficient of determination $\left(\mathrm{R}^{2}\right)$, for which the constants "a" and " $b$ " represent the y-intercept and slope of the curve, respectively. Confidence interval at $95 \%$ probability was used for $\mathrm{D}_{\mathrm{v} 0.1}, \mathrm{D}_{\mathrm{v} 0.5}$, and $\mathrm{D}_{\mathrm{v} 0.9}$ comparisons, in order to produce a graphical representation of cumulative volume fraction, using SigmaPlot, version 11.0 (Systat Software Inc., Chicago, IL, USA).

\section{Results and Discussion}

The polymer and ammonium sulfate adjuvants increased the droplet size across nozzle types (Figure 2). Through AIXR nozzle, dicamba alone and dicamba 
+ phosphatidylcholine produced similar $\mathrm{D}_{\mathrm{v} 0.5}$. When sprayed through XR nozzle, which produced the finest droplets, the adjuvants increased the droplet size in relation to dicamba alone. When sprayed through TTI nozzle, which produced the coarsest droplets, vegetable oil and phosphatidylcholine reduced the $\mathrm{D}_{\mathrm{v} 0.5}$ by 18 and $23 \%$, respectively, in comparison to dicamba alone. These adjuvants lost their drift-reducing effect as droplet size was increased with the use of air-induction nozzles, which may indicate that these adjuvants have a great efficiency only when finer droplets are used. Miller \& Butler Ellis (2000) showed that surfactants, such as phosphatidylcholine, may increase the droplet size, when they are sprayed through air-induction nozzles, differently from that observed in the present study. However, according to these authors, not all airinduction nozzles respond in the same way.

In general, the TTI air-induction nozzle produced the lowest $\mathrm{V}_{100}$ values across the evaluated solutions, ranging from 0.04 to $0.33 \%$ (Figure 3). Oppositely, when dicamba alone was sprayed, the XR nozzle produced the highest amount of droplets prone to drift, followed by TT and AIXR nozzles, with $V_{100}$ values up to 19,7 , and $2 \%$, respectively. Both air-induction nozzles (AIXR and TTI) produced similar $\mathrm{V}_{100}$ values, when polymer and ammonium sulfate were combined with dicamba. Comparisons between XR and AIXR nozzles, and between TT and TTI nozzles showed, respectively, 89 and $95 \%$ reduction of the potential risk of drift, when the air-induction nozzles were used for applications of dicamba alone.

All adjuvants reduced the $\mathrm{V}_{100}$ in relation to dicamba alone, regardless of the nozzle. For the TTI nozzle, the lowest $\mathrm{V}_{100}$ values were produced using dicamba with vegetable oil $(0.03 \%)$ and phosphatidylcholine $(0.04 \%)$, which can be related to their small droplet size (Figure 2). Vegetable oil and phosphatidylcholine had opposite behaviors when nonair-induction nozzles were used, as vegetable oil produced $1.2 \%$ more droplets prone to drift than phosphatidylcholine, when sprayed through XR, and $1.0 \%$ less droplets when sprayed through TT nozzles. Nozzle performance depends on the interaction between the spray liquid properties and nozzle design. The effect of a particular formulation sprayed through one nozzle may not be the same when

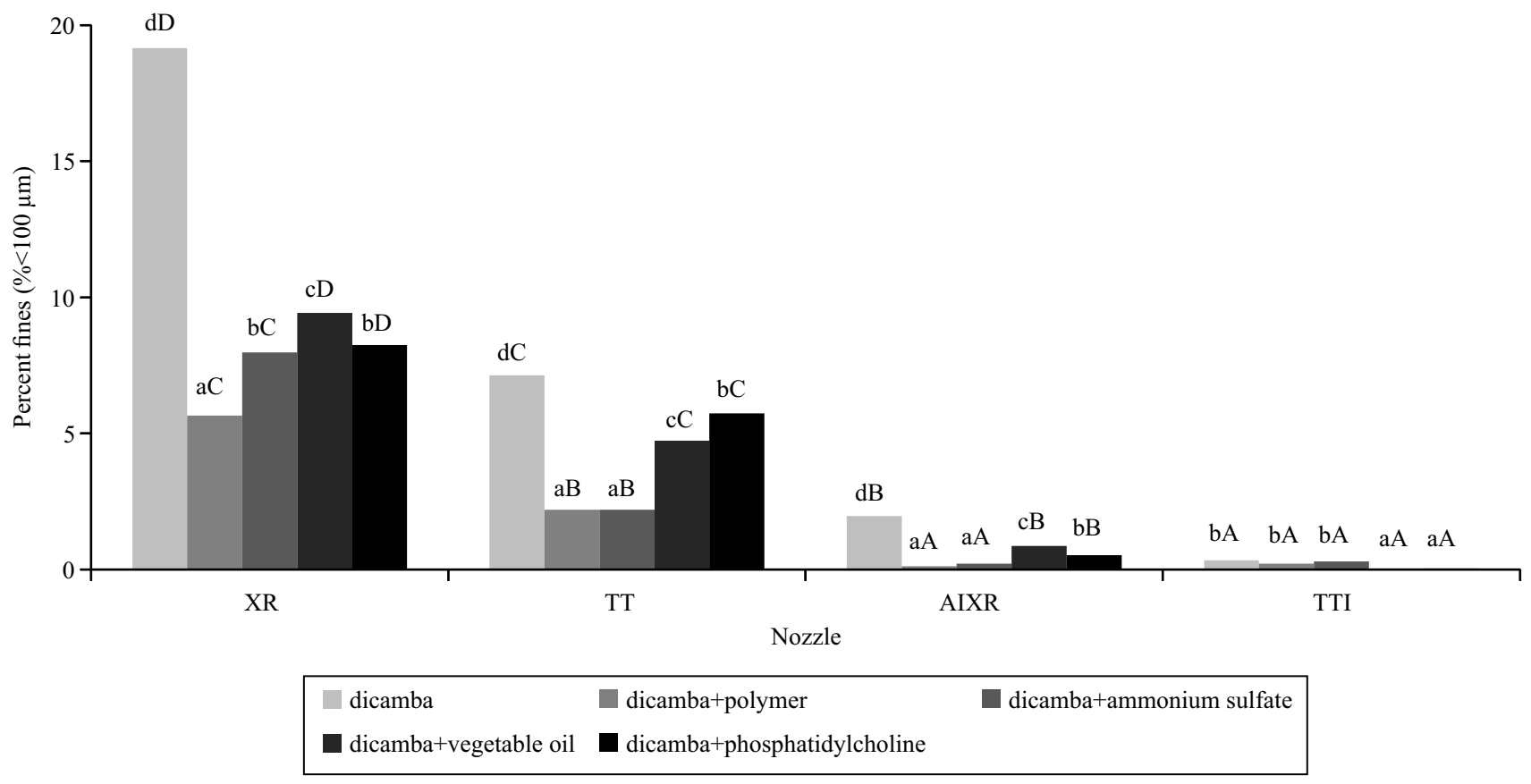

Figure 3. Volume percentage of droplets smaller than $100 \mu \mathrm{m}$ produced through different nozzle types, in applications of dicamba alone, or with adjuvants. Comparisons between solutions, within nozzle type, and between nozzles, within solution, are represented by lowercases and uppercases, respectively. Same letters represent no statistical difference using the Tukey's test at $\alpha=0.05$. $\mathrm{F}_{\text {nozzle x solution }}=72.6^{* *}$, significant at $\alpha=0.01$. 
sprayed through a different nozzle design (Butler Ellis \& Tuck, 1999).

Dicamba spray drift depended on the interaction between nozzle type and adjuvant, as observed for droplet spectrum. The XR nozzle produced the highest percentage of drift, until $6 \mathrm{~m}$ downwind from the nozzle, with all dicamba solutions, except for phosphatidylcholine (Table 2). Drift reached up to $83.1 \%$, at $2 \mathrm{~m}$, and up to $27.2 \%$ at $6 \mathrm{~m}$. The XR and TT nozzles produced similar drift in the distances from 3 to $12 \mathrm{~m}$, when phosphatidylcholine was added to dicamba solution. The TTI nozzle produced the lowest percentage of drift with dicamba alone, varying from $10.8 \%$, at $2 \mathrm{~m}$, to $0.4 \%$ at $12 \mathrm{~m}$. In the second run, the air-induction nozzles produced similar drift at $12 \mathrm{~m}$ for all adjuvants, a fact that was observed in the first run only for polymer.

In the first run, the addition of adjuvants to dicamba solutions reduced the drift across all distances using the XR nozzle, but only up to $6 \mathrm{~m}$ using the AIXR nozzle. At distances up to $5 \mathrm{~m}$, the addition of polymer reduced the drift, compared to the other adjuvants sprayed through XR, TT, and AIXR nozzles. Using nonair-induction nozzles, the polymer reduced the

Table 2. Drift percentage in applications of dicamba alone, with adjuvants through flat fan nozzles in the two experimental runs $^{(1)}$.

\begin{tabular}{|c|c|c|c|c|c|c|c|c|c|c|}
\hline \multirow[t]{2}{*}{ Nozzle } & \multicolumn{5}{|c|}{ Solution (Run 1) ${ }^{(1)}$} & \multicolumn{5}{|c|}{ Solution (Run 2) } \\
\hline & $\begin{array}{l}\text { Dicamba } \\
\text { (D) }\end{array}$ & $\mathrm{D}+$ polymer & $\begin{array}{c}\mathrm{D}+\text { ammonium } \\
\text { sulfate }\end{array}$ & $\begin{array}{c}\mathrm{D}+ \\
\text { vegetable oil }\end{array}$ & $\begin{array}{c}\mathrm{D}+ \\
\text { phosphatidylcholine }\end{array}$ & Dicamba & $\mathrm{D}+$ polymer & $\begin{array}{c}\mathrm{D}+\begin{array}{c}\text { ammonium } \\
\text { sulfate }\end{array} \\
\end{array}$ & $\begin{array}{c}\mathrm{D}+ \\
\text { vegetable oil } \\
\end{array}$ & $\begin{array}{c}\mathrm{D}+ \\
\text { phosphatidylcholine }\end{array}$ \\
\hline & \multicolumn{10}{|c|}{$2.0 \mathrm{~m}$} \\
\hline $\mathrm{XR}$ & $83.1 \mathrm{dD}$ & $42.7 \mathrm{aD}$ & $59.4 \mathrm{bD}$ & $66.5 \mathrm{cD}$ & $61.7 \mathrm{bD}$ & $71.4 \mathrm{cD}$ & $40.3 \mathrm{aD}$ & $43.9 \mathrm{aD}$ & $68.4 \mathrm{bcD}$ & $64.5 \mathrm{bD}$ \\
\hline TT & $50.8 \mathrm{cC}$ & $18.9 \mathrm{aC}$ & $31.4 \mathrm{bC}$ & $50.8 \mathrm{cC}$ & $56.2 \mathrm{dC}$ & $47.3 \mathrm{cC}$ & $16.4 \mathrm{aC}$ & $27.9 \mathrm{bC}$ & $53.7 \mathrm{dC}$ & $57.4 \mathrm{dC}$ \\
\hline AIXR & $35.0 \mathrm{~dB}$ & $7.5 \mathrm{aB}$ & $12.8 \mathrm{bB}$ & $25.9 \mathrm{cB}$ & $27.1 \mathrm{cB}$ & $32.3 \mathrm{cB}$ & $4.9 \mathrm{aB}$ & $9.4 \mathrm{bB}$ & $29.0 \mathrm{cB}$ & $31.1 \mathrm{cB}$ \\
\hline \multirow[t]{2}{*}{ TTI } & $10.8 \mathrm{cA}$ & $1.9 \mathrm{aA}$ & $3.7 \mathrm{bA}$ & $13.2 \mathrm{dA}$ & $15.9 \mathrm{eA}$ & $10.8 \mathrm{bA}$ & $1.2 \mathrm{aA}$ & $2.8 \mathrm{aA}$ & $14.7 \mathrm{bcA}$ & $18.5 \mathrm{cA}$ \\
\hline & \multicolumn{10}{|c|}{$3.0 \mathrm{~m}$} \\
\hline $\mathrm{XR}$ & $61.1 \mathrm{dD}$ & $28.4 \mathrm{aD}$ & $42.8 \mathrm{bD}$ & $47.4 \mathrm{cD}$ & $44.3 \mathrm{bcC}$ & $53.7 \mathrm{cD}$ & $26.3 \mathrm{aD}$ & $29.7 \mathrm{aD}$ & $49.9 \mathrm{bcD}$ & $46.2 \mathrm{bC}$ \\
\hline TT & $36.7 \mathrm{cC}$ & $12.3 \mathrm{aC}$ & $21.0 \mathrm{bC}$ & $37.7 \mathrm{cC}$ & $41.7 \mathrm{dC}$ & $34.8 \mathrm{cC}$ & $9.8 \mathrm{aC}$ & $17.5 \mathrm{bC}$ & $40.4 \mathrm{cdC}$ & $43.7 \mathrm{dC}$ \\
\hline AIXR & $20.5 \mathrm{~dB}$ & $4.2 \mathrm{aB}$ & $6.8 \mathrm{bB}$ & $15.2 \mathrm{cB}$ & $15.4 \mathrm{cB}$ & $18.7 \mathrm{bB}$ & $3.9 \mathrm{aB}$ & $5.1 \mathrm{aB}$ & $17.0 \mathrm{bB}$ & $17.3 \mathrm{bB}$ \\
\hline \multirow[t]{2}{*}{ TTI } & $5.2 \mathrm{cA}$ & $1.1 \mathrm{aA}$ & $1.9 \mathrm{bA}$ & $6.6 \mathrm{cA}$ & $8.7 \mathrm{dA}$ & $5.4 \mathrm{bA}$ & $0.9 \mathrm{aA}$ & $2.2 \mathrm{aA}$ & 7.6bcA & $9.7 \mathrm{cA}$ \\
\hline & \multicolumn{10}{|c|}{$4.0 \mathrm{~m}$} \\
\hline $\mathrm{XR}$ & $45.5 \mathrm{dD}$ & $19.3 \mathrm{aD}$ & $30.9 \mathrm{bD}$ & $34.5 \mathrm{cD}$ & $31.9 \mathrm{bcC}$ & $39.7 \mathrm{cD}$ & $18.4 \mathrm{aD}$ & $21.9 \mathrm{aD}$ & $36.2 \mathrm{bcD}$ & $32.6 \mathrm{bC}$ \\
\hline TT & $25.9 \mathrm{cC}$ & $8.1 \mathrm{aC}$ & $14.0 \mathrm{bC}$ & $26.5 \mathrm{cdC}$ & $29.1 \mathrm{dC}$ & $25.5 \mathrm{cC}$ & $6.3 \mathrm{aC}$ & $11.7 \mathrm{bC}$ & $28.3 \mathrm{cC}$ & $30.4 \mathrm{cC}$ \\
\hline AIXR & $13.1 \mathrm{~dB}$ & $2.7 \mathrm{aB}$ & $4.4 \mathrm{bB}$ & $9.1 \mathrm{cB}$ & $9.7 \mathrm{cB}$ & $11.5 \mathrm{bB}$ & $2.1 \mathrm{aB}$ & $3.2 \mathrm{aB}$ & $10.5 \mathrm{bB}$ & $10.5 \mathrm{bB}$ \\
\hline \multirow[t]{2}{*}{ TTI } & $2.8 \mathrm{bA}$ & $0.6 \mathrm{aA}$ & $1.0 \mathrm{aA}$ & $3.3 \mathrm{bA}$ & $4.5 \mathrm{cA}$ & $3.0 \mathrm{bA}$ & $0.7 \mathrm{aA}$ & $0.9 \mathrm{aA}$ & $4.1 \mathrm{bA}$ & $5.0 \mathrm{bA}$ \\
\hline & \multicolumn{10}{|c|}{$5.0 \mathrm{~m}$} \\
\hline $\mathrm{XR}$ & $34.4 \mathrm{cD}$ & $13.2 \mathrm{aD}$ & $23.1 \mathrm{bD}$ & $24.9 \mathrm{bD}$ & $23.1 \mathrm{bC}$ & $29.9 \mathrm{cD}$ & $12.9 \mathrm{aD}$ & $15.0 \mathrm{aC}$ & $25.9 \mathrm{bcD}$ & $23.9 \mathrm{bC}$ \\
\hline $\mathrm{TT}$ & $18.7 \mathrm{cC}$ & $5.7 \mathrm{aC}$ & $9.9 \mathrm{bC}$ & $19.0 \mathrm{cdC}$ & $21.5 \mathrm{dC}$ & $18.3 \mathrm{cC}$ & $4.5 \mathrm{aC}$ & $7.8 \mathrm{bB}$ & $19.5 \mathrm{cC}$ & $21.5 \mathrm{cC}$ \\
\hline AIXR & $8.5 \mathrm{~dB}$ & $1.7 \mathrm{aB}$ & $2.8 \mathrm{bB}$ & $5.8 \mathrm{cB}$ & $6.3 \mathrm{cB}$ & $7.8 \mathrm{bB}$ & $1.4 \mathrm{aB}$ & $1.9 \mathrm{aA}$ & $6.8 \mathrm{bB}$ & $6.6 \mathrm{bB}$ \\
\hline \multirow[t]{2}{*}{ TTI } & $1.6 \mathrm{bA}$ & $0.4 \mathrm{aA}$ & $0.6 \mathrm{aA}$ & $1.8 \mathrm{bcA}$ & $2.6 \mathrm{cA}$ & $1.9 \mathrm{bcA}$ & $0.2 \mathrm{aA}$ & $0.9 \mathrm{abA}$ & $2.2 \mathrm{bcA}$ & $3.0 \mathrm{cA}$ \\
\hline & \multicolumn{10}{|c|}{$6.0 \mathrm{~m}$} \\
\hline $\mathrm{XR}$ & $27.2 \mathrm{cD}$ & $9.8 \mathrm{aD}$ & $18.1 \mathrm{bD}$ & $19.5 \mathrm{bD}$ & $17.9 \mathrm{bC}$ & $23.4 \mathrm{cD}$ & $9.5 \mathrm{aD}$ & $11.0 \mathrm{aD}$ & $19.6 \mathrm{bcD}$ & $18.0 \mathrm{bC}$ \\
\hline TT & $13.9 \mathrm{cC}$ & $4.2 \mathrm{aC}$ & $7.4 \mathrm{bC}$ & $13.9 \mathrm{cC}$ & $15.8 \mathrm{cC}$ & $13.8 \mathrm{bC}$ & $3.3 \mathrm{aC}$ & $5.6 \mathrm{aC}$ & $14.2 \mathrm{bC}$ & $15.8 \mathrm{bC}$ \\
\hline AIXR & $6.0 \mathrm{cB}$ & $1.2 \mathrm{aB}$ & $1.9 \mathrm{aB}$ & $4.1 \mathrm{bB}$ & $4.3 \mathrm{bB}$ & $5.4 \mathrm{bB}$ & $0.9 \mathrm{aB}$ & $1.6 \mathrm{aB}$ & $4.7 \mathrm{bB}$ & $4.5 \mathrm{bB}$ \\
\hline \multirow[t]{2}{*}{ TTI } & $1.0 \mathrm{bA}$ & $0.3 \mathrm{aA}$ & $0.3 \mathrm{aA}$ & $1.1 \mathrm{bA}$ & $1.7 \mathrm{bA}$ & $1.1 \mathrm{bcA}$ & $0.1 \mathrm{aA}$ & $0.4 \mathrm{abA}$ & $1.4 \mathrm{bcA}$ & $1.9 \mathrm{cA}$ \\
\hline & \multicolumn{10}{|c|}{$7.0 \mathrm{~m}$} \\
\hline XR & $21.5 \mathrm{cD}$ & $7.5 \mathrm{aD}$ & $14.0 \mathrm{bD}$ & $14.9 \mathrm{bD}$ & $13.9 \mathrm{bD}$ & $18.5 \mathrm{cD}$ & $7.2 \mathrm{aC}$ & $8.9 \mathrm{aC}$ & $15.6 \mathrm{bcD}$ & $13.8 \mathrm{bC}$ \\
\hline TT & $10.6 \mathrm{cC}$ & $3.2 \mathrm{aD}$ & $5.7 \mathrm{bC}$ & $10.4 \mathrm{cC}$ & $11.7 \mathrm{cC}$ & $10.7 \mathrm{bC}$ & $2.5 \mathrm{aB}$ & $4.5 \mathrm{aB}$ & $10.9 \mathrm{bC}$ & $12.0 \mathrm{bC}$ \\
\hline AIXR & $4.3 \mathrm{cB}$ & $0.9 \mathrm{aB}$ & $1.4 \mathrm{aB}$ & $2.9 \mathrm{bB}$ & $3.1 \mathrm{bcB}$ & $4.1 \mathrm{bB}$ & $0.8 \mathrm{aA}$ & $1.3 \mathrm{aA}$ & $3.4 \mathrm{bB}$ & $3.3 \mathrm{bB}$ \\
\hline \multirow[t]{2}{*}{ TTI } & $0.7 \mathrm{bA}$ & $0.2 \mathrm{aA}$ & $0.2 \mathrm{aA}$ & $0.8 \mathrm{bA}$ & $1.1 \mathrm{bA}$ & $0.9 \mathrm{abA}$ & $0.2 \mathrm{aA}$ & $0.6 \mathrm{abA}$ & 1.1abA & $1.3 \mathrm{bA}$ \\
\hline & \multicolumn{10}{|c|}{$12.0 \mathrm{~m}$} \\
\hline $\mathrm{XR}$ & $8.1 \mathrm{cD}$ & $2.6 \mathrm{aC}$ & $5.1 \mathrm{bD}$ & $5.0 \mathrm{bD}$ & $3.9 \mathrm{bC}$ & $6.8 \mathrm{cD}$ & $2.4 \mathrm{aC}$ & 3.2abB & $5.4 \mathrm{bcB}$ & $4.8 \mathrm{bcB}$ \\
\hline TT & $3.7 \mathrm{cC}$ & $1.2 \mathrm{aB}$ & $1.9 \mathrm{bC}$ & $3.4 \mathrm{cC}$ & $3.8 \mathrm{cC}$ & $3.7 \mathrm{bC}$ & $0.9 \mathrm{aB}$ & 1.9abB & $3.5 \mathrm{bB}$ & $3.8 \mathrm{bB}$ \\
\hline AIXR & $1.3 \mathrm{cB}$ & $0.3 \mathrm{aA}$ & $0.4 \mathrm{abB}$ & $0.8 \mathrm{bcB}$ & $0.9 \mathrm{bcB}$ & $1.3 \mathrm{aB}$ & $0.4 \mathrm{aAB}$ & $0.4 \mathrm{aA}$ & $1.1 \mathrm{aA}$ & $1.1 \mathrm{aA}$ \\
\hline TTI & $0.2 \mathrm{aA}$ & $0.1 \mathrm{aA}$ & $0.1 \mathrm{aA}$ & $0.2 \mathrm{aA}$ & $0.3 \mathrm{aA}$ & $0.4 \mathrm{aA}$ & $0.1 \mathrm{aA}$ & $0.2 \mathrm{aA}$ & $0.4 \mathrm{aA}$ & $0.4 \mathrm{aA}$ \\
\hline
\end{tabular}

(1) Means followed by equal letters, within each evaluated distance and run, lowercase in the rows and uppercase in the columns, do not differ by the Tukey's test, at $5 \%$ probability. 
drift from 2 to $12 \mathrm{~m}$. Beyond $6 \mathrm{~m}$, dicamba with polymer and ammonium sulfate produced similar drift when sprayed through the air-induction nozzles. At 12 $\mathrm{m}$, the adjuvants vegetable oil and phosphatidylcholine did not reduce drift in comparison with dicamba alone, when AIXR nozzle was used. For TT and TTI nozzles, the adjuvant phosphatidylcholine increased the drift in relation to dicamba alone, at distances up to $5 \mathrm{~m}$. At 5 $\mathrm{m}$, this adjuvant increased the drift by 15 and $62 \%$, in comparison to dicamba alone, when sprayed through TT and TTI nozzle, respectively. At further distances, there was no difference between dicamba alone and solutions of dicamba with phosphatidylcholine and vegetable oil. These two adjuvants reduced the size of droplets produced through TT and TTI nozzles, which, consequently, increased the drift in relation to dicamba alone, even though producing lower $\mathrm{V}_{100}$.

In general, the results obtained in the first run were sustained in the second one. The highest and lowest percentages of drift from dicamba alone, or in solution with adjuvants, were generated through XR and TTI nozzles, respectively. The air-induction nozzles produced lower drift than nonair-induction nozzles across distances and dicamba solutions; however, the TT and AIXR nozzles produced a similar drift at 12 $\mathrm{m}$, when dicamba was sprayed with polymer. When spraying dicamba with phosphatidylcholine, the XR and TT nozzles produced a similar drift, from 3 to $12 \mathrm{~m}$. At $12 \mathrm{~m}$, the AIXR and TTI nozzles produced percentages of drift from 0.1 to $1.1 \%$, for dicamba with adjuvants solutions. Dicamba with polymer and ammonium sulfate reduced the drift, in comparison to dicamba alone sprayed through XR, TT, and AIXR nozzle, until $7 \mathrm{~m}$. Dicamba with vegetable oil and phosphatidylcholine, and dicamba alone sprayed through TT, AIXR, and TTI nozzles, produced a similar drift at 4, 5, 6, 7, and $12 \mathrm{~m}$. Drift from dicamba with phosphatidylcholine was 1.7 and 1.8 times greater than drift from dicamba alone, using the TTI nozzle, at 2 and $3 \mathrm{~m}$, respectively. Dicamba solutions, associated or not with drift-reducing adjuvants, produced similar results at $12 \mathrm{~m}$ using air-induction nozzles.

Johnson et al. (2006) evaluated a glyphosate spray drift with drift-reducing nozzles and adjuvants on sorghum, and also observed that air-induction (AI) nozzles considerably reduced the drift, in comparison to XR nozzle, however, they were not significant in relation to TT nozzles. The authors observed that the polymer reduced the drift when sprayed through AI nozzle, but not through XR nozzles. Their results are not in accordance with results from the present study because we observed that dicamba drift was reduced when polymer was added to the solution sprayed through nonair-induction nozzles. Oliveira et al. (2013) measured drift from 30 solutions with adjuvants sprayed through XR 8003 nozzle in a wind tunnel. Similarly to what was observed in the first run of the present study, the authors observed that vegetable oil reduced the drift, in comparison to the solution without adjuvants. Hilz \& Vermeer (2013) reported that nozzle type has a more expressive influence on drift reduction than the formulated product or the spray additive. Drift-reducing adjuvants should be used when their effects are known, in order to avoid undesirable results, such as those observed for the combination between phosphatidylcholine and TTI nozzle. The effects of formulation and spray solution on drift using air-induction nozzles are less predictable, since the relationships between drift and spray characteristics for these nozzles are less understood (Miller \& Butler Ellis, 2000).

In both runs, the percentage of drift from dicamba applications through XR, TT, and AIXR nozzles decreased exponentially, as distance from the nozzles increased, as well as from dicamba alone and dicamba with vegetable oil and phosphatidylcholine sprayed through TTI nozzle (Figure 4). All significant regression models were adjusted by two-parameter exponential functions $\left(\hat{y}=a^{-b x}\right)$, with coefficient of determination values above $99 \%$ (Table 3). Data generated with dicamba applications through TTI nozzle using polymer did not fit any model in any run, even in the second run, when ammonium sulfate was used. The coefficient "a" reduced as droplet size increased, which indicates a tendency of the models to linearity as droplet size increased, even though this model was not significant in any situation.

As previously described, polymer and ammonium sulfate were the adjuvants with better capacity of drift reduction; however, there is lack of information related to their effects on efficacy when associated with dicamba. In addition, ammonium sulfate should be used with caution when added to dicamba solutions due to increase volatility potential by reducing the $\mathrm{pH}$ of the spray solution (Zollinger, 2017). Although this adjuvant has potential to reduce particle drift, as shown 

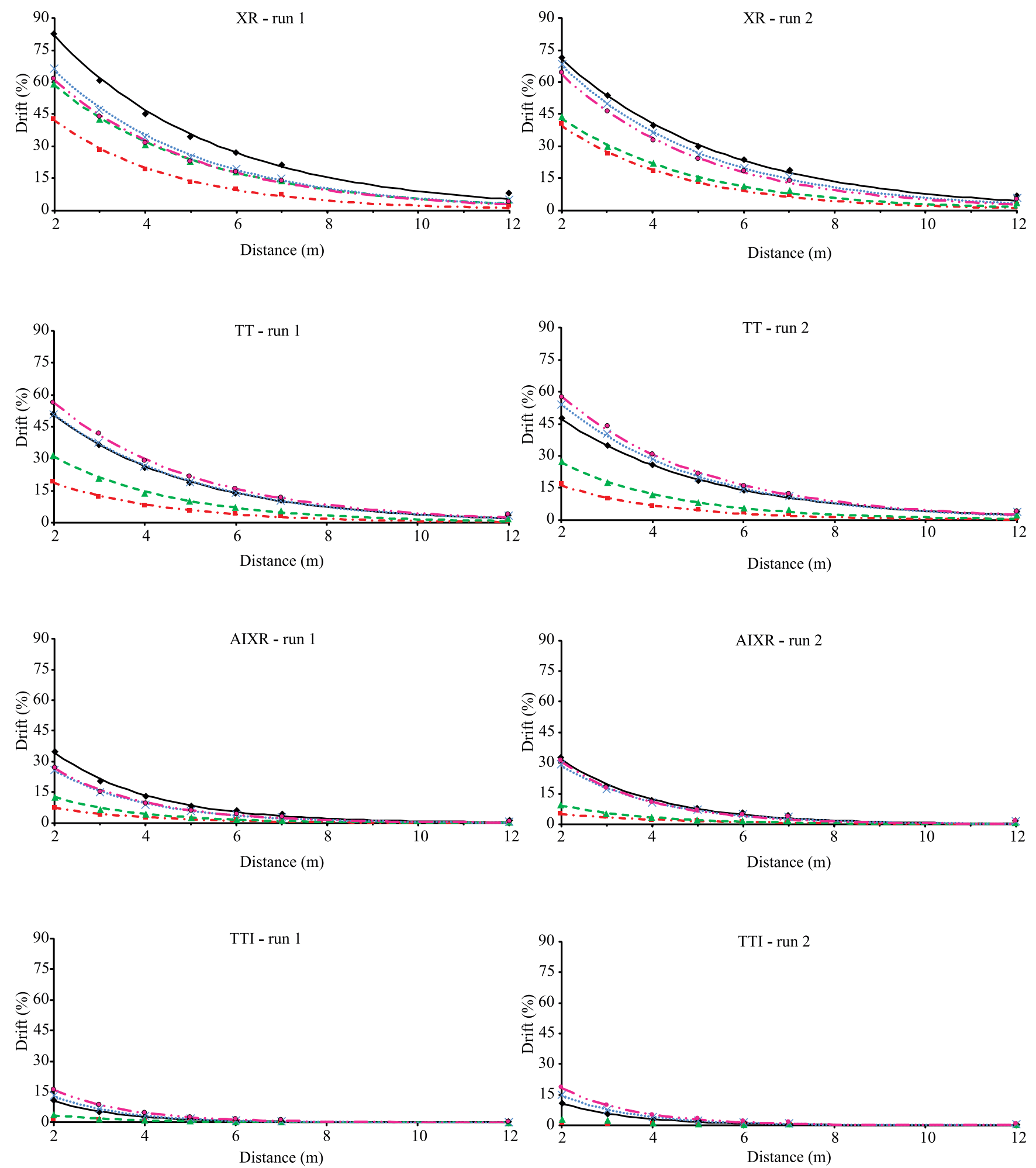

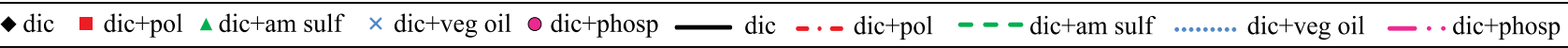

Figure 4. Drift curves from applications of dicamba alone, or with adjuvants, through different nozzle types in wind tunnel, in two experimental runs. Dic, dicamba; pol, polymer; am sulf, ammonium sulfate; veg oil, vegetable oil; phosp, phosphatidylcholine. 
Table 3. Regression analysis obtained with data from applications of five dicamba solutions sprayed through different nozzle types, in two experimental runs.

\begin{tabular}{|c|c|c|c|c|c|c|c|c|}
\hline \multirow[t]{3}{*}{ Solution $^{(1)}$} & \multicolumn{8}{|c|}{ Nozzle } \\
\hline & \multicolumn{2}{|l|}{$\mathrm{XR}$} & \multicolumn{2}{|l|}{ AIXR } & \multicolumn{2}{|l|}{ TT } & \multicolumn{2}{|l|}{ TTI } \\
\hline & Function & $\mathrm{R}^{2}$ & Function & $\mathrm{R}^{2}$ & Function & $\mathrm{R}^{2}$ & Function & $\mathrm{R}^{2}$ \\
\hline & \multicolumn{8}{|c|}{ Run 1} \\
\hline Dicamba (D) & $\hat{\mathrm{y}}=142.4 \mathrm{e}^{-0.2775 \mathrm{x}}$ & 99.6 & $\hat{y}=87.6 e^{-0.4666 x}$ & 99.5 & $\hat{y}=96.1 \mathrm{e}^{-0.3219 \mathrm{x}}$ & 99.8 & $\hat{y}=40.4 \mathrm{e}^{-0.6645 \mathrm{x}}$ & 99.5 \\
\hline $\mathrm{D}+$ polymer & $\hat{y}=88.9 \mathrm{e}^{-0.3735 \mathrm{x}}$ & 99.5 & $\hat{y}=19.7 \mathrm{e}^{-0.4913 x}$ & 99.2 & $\hat{y}=40.6 e^{-0.3888 x}$ & 99.4 & ns & - \\
\hline $\mathrm{D}+$ ammonium sulfate & $\hat{\mathrm{y}}=106.4 \mathrm{e}^{-0.2991 \mathrm{x}}$ & 99.6 & $\hat{y}=35.4 \mathrm{e}^{-0.5184 \mathrm{x}}$ & 99.1 & $\hat{y}=64.9 \mathrm{e}^{-0.3698 x}$ & 99.5 & $\hat{y}=12.4 \mathrm{e}^{-0.6154 \mathrm{x}}$ & 99.7 \\
\hline $\mathrm{D}+$ vegetable oil & $\hat{\mathrm{y}}=121.9 \mathrm{e}^{-0.3098 \mathrm{x}}$ & 99.7 & $\hat{y}=68.2 \mathrm{e}^{-0.4907 x}$ & 99.6 & $\hat{y}=96.6 e^{-0.3200 x}$ & 99.8 & $\hat{\mathrm{y}}=50.5 \mathrm{e}^{-0.6730 \mathrm{x}}$ & 99.9 \\
\hline \multirow{2}{*}{$\mathrm{D}+$ phosphatidylcholine } & $\hat{\mathrm{y}}=113.8 \mathrm{e}^{-0.3113 \mathrm{x}}$ & 99.8 & $\hat{\mathrm{y}}=70.4 \mathrm{e}^{-0.4874 \mathrm{x}}$ & 99.4 & $\hat{\mathrm{y}}=105.8 \mathrm{e}^{-0.3159 \mathrm{x}}$ & 99.8 & $\hat{\mathrm{y}}=53.2 \mathrm{e}^{-0.6025 \mathrm{x}}$ & 99.8 \\
\hline & \multicolumn{8}{|c|}{ Run 2} \\
\hline Dicamba (D) & $\hat{y}=123.0 e^{-0.2766 x}$ & 99.7 & $\hat{y}=82.1 \mathrm{e}^{-0.4765 x}$ & 99.3 & $\hat{y}=86.4 \mathrm{e}^{-0.3037 \mathrm{x}}$ & 99.8 & $\hat{y}=35.8 \mathrm{e}^{-0.6067 x}$ & 99.3 \\
\hline $\mathrm{D}+$ polymer & $\hat{y}=82.4 \mathrm{e}^{-0.3674 x}$ & 99.5 & $\hat{y}=11.0 \mathrm{e}^{-0.3900 x}$ & 97.5 & $\hat{y}=37.6 e^{-0.4285 x}$ & 98.9 & ns & - \\
\hline $\mathrm{D}+$ ammonium sulfate & $\hat{y}=84.9 \mathrm{e}^{-0.3388 \mathrm{x}}$ & 99.5 & $\hat{y}=24.7 \mathrm{e}^{-0.4994 x}$ & 98.6 & $\hat{y}=58.9 \mathrm{e}^{-0.3957 \mathrm{x}}$ & 99.2 & $\mathrm{~ns}$ & - \\
\hline $\mathrm{D}+$ vegetable oil & $\hat{y}=125.6 \mathrm{e}^{-0.3076 x}$ & 99.7 & $\hat{y}=74.6 \mathrm{e}^{-0.4972 x}$ & 99.6 & $\hat{y}=103.7 e^{-0.3246 x}$ & 99.7 & $\hat{y}=51.3 \mathrm{e}^{-0.6268 \mathrm{x}}$ & 99.8 \\
\hline $\mathrm{D}+$ phosphatidylcholine & $\hat{y}=121.0 e^{-0.3192 x}$ & 99.7 & $\hat{y}=85.8 \mathrm{e}^{-0.5162 x}$ & 99.5 & $\hat{y}=109.3 e^{-0.3174 x}$ & 99.7 & $\hat{y}=62.9 \mathrm{e}^{-0.6165 \mathrm{x}}$ & 99.7 \\
\hline
\end{tabular}

in this study, the increased volatility observed from dicamba applications may not warrant the addition in tank-mixtures due to the high propensity to cause problems from off-target movement at extremely low doses. Therefore, efficacy and volatilization assays are needed to achieve a comprehensive recommendation on the use of drift-reducing adjuvants, mainly when air-induction nozzles are used, to maximize herbicide efficacy while mitigating drift as much as possible.

\section{Conclusions}

1. Droplet spectrum and dicamba drift depend on the interaction between spray composition and nozzle type.

2. As the air-induction nozzles produce less droplets prone to drift, and lower percentage of drift from 2 to $12 \mathrm{~m}$, in comparison to nonair-induction ones, they should be used to spray dicamba.

3. The adjuvants have better results on the reduction of drift potential at closer distances from the nozzle; and drift decreases exponentially in applications through XR, TT, and AIXR as the distance from the nozzles increases.

4. Vegetable oil and phosphatidylcholine associated with dicamba reduce the droplet size in relation to dicamba alone when sprayed through TTI nozzle, while polymer and ammonium sulfate increase the droplet size for all nozzle types, which may reduce damages caused by drift to nearby crops.

\section{Acknowledgments}

To Coordenação para o Aperfeiçoamento de Pessoal de Nível Superior (Capes), for financial support; and to the research group of Pesticide Application Technology Laboratory, for their support.

\section{References}

ANDERSEN, S.M.; CLAY, S.A.; WRAGE, L.J.; MATTHEES, D. Soybean foliage residues of dicamba and 2,4-D and correlation to application rates and yield. Agronomy Journal, v.96, p.750-760, 2004.

BEHRENS, M.R.; MUTLU, N.; CHAKRABORTY, S.; DUMITRU, R.; JIANG, W.Z.; LAVALLEE, B.J.; HERMAN, P.L.; CLEMENTE, T.E.; WEEKS, D.P. Dicamba resistance: enlarging and preserving biotechnology-based weed management strategies. Science, v.316, p.1185-1188, 2007. DOI: 10.1126/ science. 1141596 .

BUTLER ELLIS, M.C.; TUCK, C.R. How adjuvants influence spray formation with different hydraulic nozzles. Crop Protection, v.18, p.101-109, 1999. DOI: 10.1016/S0261-2194(98)00097-0.

DERKSEN, D.A. Dicamba, chlorsulfuron, and clopyralid as sprayer contaminants on sunflower (Helianthus annuus), mustard (Brassica juncea), and lentil (Lens culinaris), respectively. Weed Science, v.37, p.616-621, 1989.

EGAN, J.F.; BARLOW, K.M.; MONTERSEN, D.A. A metaanalysis on the effects of 2,4-D and dicamba drift on soybean and cotton. Weed Science, v.62, p.193-206, 2014. DOI: 10.1614/WSD-13-00025.1.

FERREIRA, D.F. A computer statistical analysis system. Ciência e Agrotecnologia, v.35, p.1039-1042, 2011. DOI: 10.1590/S141370542011000600001 . 
FRITZ, B.K.; HOFFMANN, W.C.; BAGLEY, W.E.; KRUGER, G.R.; CZACZYK, Z.; HENRY, R.S. Measuring droplet size of agricultural spray nozzles-measurement distance and airspeed effects. Atomization and Sprays, v.24, p.747-760, 2014.

HADERLIE, L.C.; PETERSEN, P.J.; LEINO, P.W. Potato seed vigor and yield potential following herbicide drift and carryover. Weed Science, p.324-327, 1986.

HEAP, I. The international survey of herbicide resistant weeds. 2017. Available at: <http://weedscience.org/>. Accessed on: 28 Aug., 2017.

HILZ, E.; VERMEER, A.W.P. Spray drift review: the extent to which a formulation can contribute to spray drift reduction. Crop Protection, v.44, p.75-83, 2013. DOI: 10.1016/j. cropro.2012.10.020.

HOFFMANN, W.C.; FRITZ, B.K.; LEDEBUHR, M.A. Evaluation of 1, 3, 6, 8-pyrene tetra sulfonic acid tetra sodium salt (PTSA) as an agricultural spray tracer dye. Applied Engineering in Agriculture, v.30, p.25-28, 2014. DOI: 10.13031/ aea.30.10313.

HOFFMANN, W.C.; FRITZ, B.K.; THORNBURG, J.W.; BAGLEY, W.E.; BIRCHFIELD, N.B.; ELLENBERGER, J. Spray drift reduction evaluations of spray nozzles using a standardized testing protocol. Journal of ASTM International, v.7, p.1-8, 2010. DOI: $10.1520 / J A I 102820$.

ISO. INTERNATIONAL ORGANIZATION FOR STANDARDIZATION. ISO 22856: Equipment for crop protection - methods for the laboratory measurement of spray drift - wind tunnels. Geneva, 2008. 14p.

JOHNSON, A.K.; ROETH, F.W.; MARTIN, A.R.; KLEIN, R.N. Glyphosate spray drift management with drift-reducing nozzles and adjuvants. Weed Technology, v.20, p.893-897, 2006. DOI: 10.1614/WT-05-162.1.

MILLER, P.C.H.; BUTLER ELLIS, M.C. Effects of formulation on spray nozzle performance for applications from ground-based boom sprayers. Crop Protection, v.19, p.609-615, 2000. DOI: 10.1016/S0261-2194(00)00080-6.

OLIVEIRA, R.B. de; ANTUNIASSI, U.R.; MOTA, A.A.B.; CHECHETTO, R.G. Potential of adjuvants to reduce drift in agricultural spraying. Engenharia Agrícola, v.34, p.986-992, 2013. DOI: $10.1590 /$ S0100-69162013000500010.

SPANOGHE, P.; DE SCHAMPHELEIRE, M.; VAN DER MEEREN, P.; STEURBAUT, W. Influence of agricultural adjuvants on droplet spectra. Pest Management Science, v.63, p.4-16, 2007. DOI: $10.1002 / p s .1321$.

ZOLLINGER, R. Why no AMS is allowed with dicamba in dt soybean. 2017. Available at: $<$ https://www.ag.ndsu.edu/cpr/weeds/ why-no-ams-is-allowed-with-dicamba-in-dt-soybean-06-22-17>. Accessed on: 21 Aug. 2018.

WEIDENHAMER, J.D.; TRIPLETT JR., G.B.; SOBOTKA, F.E. Dicamba injury to soybean. Agronomy Journal, v.81, p.637-643, 1989. DOI: 10.2134/agronj1989.00021962008100040017x.

$\overline{\text { Received on July 3, } 2017 \text { and accepted on September 29, } 2017}$ 